\title{
New Syntheses of Branched, Multifunctional High-Molecular Weight Poly(ethylene glycol)s or (MultiPEG)s
}

\author{
Sara Drioli ${ }^{\mathrm{a}}$, Gian Maria Bonora ${ }^{*, \mathrm{a}}$ and Maurizio Ballico ${ }^{\mathrm{b}}$ \\ ${ }^{a}$ Department of Chemical Science - University of Trieste - Via Giorgieri 1-34127 - Trieste, Italy \\ ${ }^{b}$ Department of Chemical Science - University of Udine - Via del Cotonificio - 33100 - Udine, Italy
}

\begin{abstract}
A new set of branched high-molecular weight multifunctional poly(ethylene glycol) (MultiPEG) derivatives was obtained from smaller commercial diOH-PEGs (M.W. $=2000$ and $6000 \mathrm{Da}$ ) which were selectively monoprotected, properly activated at the residual $\mathrm{OH}$-functions and treated with 1,3-diamino-2-propanol and 2-amino-1,3-propandiol as polyfunctional linkers. They were purified by molecular exclusion chromatography or extensive dialysis and characterized by GPC and ${ }^{1} \mathrm{H}-\mathrm{NMR}$. The final polymeric derivatives are characterized by a higher number of terminal reacting moieties (up to 6 times) than that found in linear, commercial PEGs of same molecular size. This increased loading capability can be applied to improve their use as drug carriers and soluble synthetic supports.
\end{abstract}

Keywords: PEG, poly(ethylene glycol), branched polymers, soluble polymer, conjugate, supporting polymer.

\section{INTRODUCTION}

The use of PEG to conjugate sensitive bioactive molecules and to improve their pharmacological properties has been extensively investigated and has found many practical applications since Davis's pioneering work performed in the late 60s [1,2]. The PEG-conjugation (PEGylation) of bioactive molecules can enhance their therapeutic effect as PEG endows with its own physicochemical properties the attached molecules thereto and improves their bioavailability and solubility, thereby facilitating their administration [3]. A longer retention time in the blood circulatory system can also be observed, with an increasing effect as the molecular weight of the supporting polymer grows. Consequently, PEGylation is expected to secure a prolonged half-live of the biopharmaceutical products, reduce side effects and increase efficiency of the therapy. In this context a series of antibiotics, anticancer and antimalarial agents, for example doxorubicin, epirubicin, paclitaxel, and artemisine, as well as various enzymatic inhibitors, have been investigated [4-10]. It must also be recalled that medium-size bioactive molecules, such as peptides and oligonucleotides, have been subject of such PEG conjugations to increase their solubilisation, cellular uptake, and in vivo stability toward degradation processes $[11,12]$. Additionally, the use of PEG-based systems as inert, soluble synthetic supports in organic synthesis has been extensively exploited and evaluated for convenient applications on environment compatible synthetic processes [13,14].

Commercial PEG derivatives show good chemical and mechanical properties, terminal reactive functional groups, as well as advantageous solubilising properties. However, the reduced homogeneity of their molecular size and a low loading capacity could hamper their pharmacological application, and these adverse characteristics increase with higher molecular weight. With a view to improve their overall features, many modifications of linear bifunctional PEGs

*Address correspondence to this author at the Department of Chemical Science - University of Trieste - Via Giorgieri 1 - 34127 - Trieste, Italy; Tel: +39 040 5583927; Fax: +39040 5582400; E-mail: bonora@units.it have been proposed [15-17], but their synthesis can be complex and time-consuming and they are scarcely hydrolyzed under physiological conditions $[18,19]$. Furthermore, new dendrimeric PEG derivatives have been synthesized from commercial poly(ethylene glycol)s and low cost alcohols, but their higher loading capacities diminish significantly as the molecular size of the substrate is increased, due to a combination of steric hindrance of anchoring groups and intramolecular hydrogen bonding. Additionally, there are difficulties in the synthesis of polymers using high molecular weight PEG because of the low reactivity of the substrates [20], while similar high-capacity soluble polymeric supports, consisting of aliphatic dendritic polyethers and of hyperbranched polyethers-polyols, require a difficult multistage preparation [21-24].

Recently, we proposed a new synthetic strategy aimed at the production of branched, high-molecular weight multimeric PEGs (MultiPEGs) starting from common, commercial PEG moieties [25]. The presence of an increased number of functional groups, compared to linear PEGs of the same molecular size, and of different stability chemical bonds within the main polymeric backbone represented the main features of those derivatives. In this paper two alternative procedures are reported, characterized by an easy formation of larger polymeric systems through a more convenient process, a larger final molecular size and an increased number of functional groups.

\section{MATERIALS AND METHODOLOGY}

NMR spectra were recorded on a JEOL EX 400 spectrometer in DMSO- $d_{6}$ and $\mathrm{CDCl}_{3}$ using TMS as internal standard. UV/VIS spectra were obtained with a Helios $\beta$ UNICAM spectrophotometer. GPC analyses were performed on two columns connected in series (PL Aquagel-OH $30+$ PL Aquagel-OH $40-8 \mu \mathrm{m}(30 \times 0.75 \mathrm{~cm})$ ) (Polymer Laboratories, Lab Service Analytica s.r.l., Bologna, Italy); eluent: phosphate buffer $0.5 \mathrm{M}, \mathrm{pH} 6.0+\mathrm{NaCl} 0.5 \mathrm{M}$. A HPLC Hewlett-Packard series 1100 system equipped with a RI K2301 refractive index detector (KNAUER, Berlin, Germany) 
was used. $20 \mu \mathrm{l}$ of a solution of $6 \mathrm{mg}$ of each sample in 0.1 $\mathrm{ml} \mathrm{milliQ}$ water were injected with a flow of $1.0 \mathrm{ml} / \mathrm{minute}$.

PEG, 1,3-diamino-2-propano, 2-amino-1,3-propandiol and N,N'-disuccinimidyl carbonate (DSC) were purchased from Fluka (Buchs, Switzerland). All the organic solvents were dried over molecular sieves. The syntheses of the DMT-PEG-OH, and DMT-PEG-OSu (M.W. = 2000 and $6000 \mathrm{Da})$, as well of $\mathrm{PEG}_{2000^{-}}(\mathrm{OH})_{4}$ and $\mathrm{PEG}_{2000^{-}}(\mathrm{OSu})_{4}$ were carried out following the procedures previously described [25].

\subsection{Synthesis of pentaPEG ${ }_{2000}-(\mathrm{OH})_{12}$}

\subsubsection{Synthesis of (1,3-diamino-2-propanol) ${ }_{4}-\boldsymbol{P E G}_{2000}(A)$}

1,3-diamino-2-propanol (500 mg, 5.55 mmoles) was dissolved in anhydrous methanol $(\mathrm{MeOH})(20 \mathrm{ml})$ in a $100 \mathrm{ml}$ flask under stirring and mixed with 0.33 equivalents of triethylamine (TEA) (187.3 mg, 1.85 mmoles). The resulting solution, placed into an ice bath, was very slowly added dropwise, under stirring, to a solution of 0.33 equivalents of di- $t$-butyl-dicarbonate $\left(\mathrm{Boc}_{2} \mathrm{O}\right)(403 \mathrm{mg}, 1.85 \mathrm{mmoles})$ in methanol $(\mathrm{MeOH})(10 \mathrm{ml})$ and left to react for $18 \mathrm{~h}$. The solvent was eliminated with a rotary evaporator and the residue was mixed with a $10 \%$ citric acid solution $(25 \mathrm{ml})$. The aqueous phase was extracted with ethyl acetate (AcOEt) $(3 \mathrm{x}$ $20 \mathrm{ml}$ ) to eliminate di-Boc derivatives. The aqueous phase was basified to $\mathrm{pH} 9.0$ with a $4 \mathrm{M} \mathrm{NaOH}$ solution and extracted with AcOEt (4 x 30ml). The organic phase was dried over anhydrous $\mathrm{Na}_{2} \mathrm{SO}_{4}$, and the solvent was eliminated with a rotary evaporator. Mono-N-Boc-1,3-diamino-2-propanol was obtained as a white powder $(96 \mathrm{mg}, 28 \%)$.

${ }^{1} \mathrm{H}-\mathrm{NMR}\left(\mathrm{CDCl}_{3}\right) \delta 5.05(0.89 \mathrm{H}(1), \mathrm{m}, \mathrm{NH}$ urethane); $3.60\left(0.98 \mathrm{H}(1), \mathrm{m},-\mathrm{CH}_{2}-\underline{\mathrm{CH}}(\mathrm{OH})-\mathrm{CH}_{2}-\right) ; 3.35(0.93 \mathrm{H}(1)$, $\left.\mathrm{m}, \mathrm{Bu}^{t}-\mathrm{O}-\mathrm{CO}-\mathrm{NH}-\underline{\mathrm{CH}}_{2}\right)^{-} ; 3.10\left(0.92 \mathrm{H}(1), \mathrm{m}, \mathrm{Bu}^{t}-\mathrm{O}-\mathrm{CO}-\right.$ $\left.\mathrm{NH}-\mathrm{CH}_{2}-\right) ; 2.80\left(0.92 \mathrm{H}(1), \mathrm{m},-\mathrm{CH}_{2}-\mathrm{NH}_{2}\right) ; 2.65(0.93 \mathrm{H}(1)$, m, $\left.-\underline{\mathrm{CH}}_{2}-\mathrm{NH}_{2}\right) ; 1.47$ (9.00H (9), s, $\left.\left(\mathrm{CH}_{3}\right) \mathrm{Bu}^{t}\right)$.

$\mathrm{PEG}_{2000}-(\mathrm{OSu})_{4}(620 \mathrm{mg}, 0.221 \mathrm{mmoles})$ was coevaporated from anhydrous dichloromethane (DCM) $(10 \mathrm{ml})$ in a $250 \mathrm{ml}$ flask and dried for 30 minutes under vacuum. The residue was dissolved in anhydrous DCM $(3 \mathrm{ml})$ and the solution was mixed, under stirring, with 12.0 equivalents of mono-N-Boc-1,3-diamino-2-propanol (504 mg, 2.65 mmoles). The solution was left to react under stirring, at room temperature, for $18 \mathrm{hs}$. The product was precipitated by slow addition of anhydrous ethyl ether $(100 \mathrm{ml})$, recovered by filtration under vacuum, washed with ether, recrystallised from DCM/ether, and dried over $\mathrm{KOH}$ under vacuum (0.62 g, $98 \%)$.

${ }^{1} \mathrm{H}-\mathrm{NMR}\left(\mathrm{CDCl}_{3}\right) \delta 5.88(3.58 \mathrm{H}(4), \mathrm{m}, \mathrm{NH}$ urethane); $4.55\left(1.70 \mathrm{H}(2), \mathrm{m},-\mathrm{NH}-\underline{\mathrm{CH}}\left(\mathrm{CH}_{2}-\mathrm{O}-\mathrm{CO}-\ldots\right)_{2}\right) ; 4.19(16.43 \mathrm{H}$ (16), m, PEG- $\mathrm{CH}_{2}-\mathrm{O}-\mathrm{CO}-\mathrm{NH}-+-\mathrm{NH}-\mathrm{CH}\left(\mathrm{CH}_{2}-\mathrm{O}-\mathrm{CO}-\ldots\right)_{2}+$ $\left.-\mathrm{NH}-\mathrm{CH}_{2}-\mathrm{CH}(\mathrm{OH})-\mathrm{CH}_{2}-\mathrm{NH}-\right) ; 3.75-3.46$ (182 $\mathrm{H}$ (182), m, $\left.\left(\mathrm{CH}_{2} \mathrm{CH}_{2} \mathrm{O}\right)_{\mathrm{n}}\right) ; 3.30-3.05$ (16.70H (16), m, -O-CO-NH- $\underline{\mathrm{CH}}_{2}^{-}$ $\left.\mathrm{CH}(\mathrm{OH})-\mathrm{CH}_{2}-\mathrm{NH}-\mathrm{CO}-\mathrm{OBu}^{t}\right) ; 1.43\left(37.60 \mathrm{H}(36), \mathrm{s},\left(\mathrm{CH}_{3}\right)\right.$ $\left.\mathrm{Bu}^{t}\right)$.

(N-Boc-1,3-diamino-2-propanol $)_{4}-\mathrm{PEG}_{2000} \quad(615 \mathrm{mg}$, 0.198 mmoles) was dissolved in a $50 \%$ solution of trifluoroacetic acid (TFA) in DCM $(10 \mathrm{ml})$ and stirred for 30 minutes. Once the volume of the solution was partially reduced $(5 \mathrm{ml})$, (1,3-diamino-2-propanol $)_{4}-\mathrm{PEG}_{2000}$ was precipitated with ether according to the usual procedure. After recrystallisations from anhydrous pyridine/ether, a crystalline product was obtained $(0.49 \mathrm{~g}, 98 \%)$.

${ }^{1} \mathrm{H}-\mathrm{NMR}\left(\mathrm{DMSO}-d_{6}\right) \delta 7.78(3.65 \mathrm{H}(4), \mathrm{m}, \mathrm{NH}$ urethane); 4.80 (3.77H (4), m, OH); 4.10-3.77 (15.52H (16), m, PEG- $\mathrm{CH}_{2}-\mathrm{O}-\mathrm{CO}-\mathrm{NH}-+$ - $\mathrm{NH}-\mathrm{CH}_{2}-\mathrm{CH}(\mathrm{O}-\mathrm{CO}-\mathrm{NH}-\ldots)_{2}+-$ $\left.\mathrm{NH}-\mathrm{CH}_{2}-\mathrm{CH}(\mathrm{OH})-\mathrm{CH}_{2}-\mathrm{NH}_{2}\right) ; 3.63-3.34$ (182H (182), m, $\left.\left(\mathrm{CH}_{2} \mathrm{CH}_{2} \mathrm{O}\right)_{\mathrm{n}}\right) ; 3.15-2.55 \quad\left(15.72 \mathrm{H} \quad(16), \quad \mathrm{m}, \quad-\mathrm{NH}-\underline{\mathrm{CH}}_{2}-\right.$ $\left.\mathrm{CH}(\mathrm{OH})-\mathrm{CH}_{2}-\mathrm{NH}_{2}\right)$.

\subsubsection{Synthesis of pentaPEG ${ }_{2000}-(\mathrm{OH})_{8}(\mathrm{~B})$}

(1,3-diamino-2-propanol $)_{4}-\mathrm{PEG}_{2000} \quad(150 \quad \mathrm{mg}, \quad 0.056$ mmoles) was coevaporated from anhydrous DCM $(5 \mathrm{ml})$ in a $250 \mathrm{ml}$ flask and dried for 30 minutes under vacuum. The residue was dissolved in anhydrous DCM $(3 \mathrm{ml})$. The $\mathrm{pH}$ value of the solution was adjusted to 9.0 with TEA and the solution was very slowly mixed, under stirring, with 4.4 equivalents of DMT-PEG $2000-\mathrm{OSu}$ (598 mg, 0.246 mmoles). The mixture was left to react under stirring, at room temperature, for 72 hs. The product was precipitated by slow addition of anhydrous ethyl ether $(100 \mathrm{ml})$, recovered by filtration under vacuum, washed with ether, recrystallised from DCM/ether, and dried over $\mathrm{KOH}$ under vacuum (0.73 g, $95 \%$ ). The TNBS analysis of the product [26] indicated the residual presence of $4.8 \%$ of free amino groups.

${ }^{1} \mathrm{H}-\mathrm{NMR} \quad\left(\mathrm{DMSO}-d_{6}\right) \quad \delta \quad 7.47-7.15 \quad(38.24 \mathrm{H} \quad(36), \mathrm{m}$, DMT); 7.07 (7.33H (10), m, NH urethane); $6.87(17.22 \mathrm{H}$ (16), m, DMT); 4.81 (3.21H (4), m, OH); 4.20 (23.71H (24), m, PEG- $\mathrm{CH}_{2}-\mathrm{O}-\mathrm{CO}-\mathrm{NH}-+$ - O-CO-NH-CH$\left(\mathrm{CH}_{2}-\mathrm{O}-\ldots\right)_{2}+-$ $\left.\mathrm{NH}-\mathrm{CH}_{2}-\mathrm{CH}(\mathrm{OH})-\mathrm{CH}_{2}-\mathrm{NH}-\right) ; 3.74-3.40$ (909H (909), m, $\left.\left(\mathrm{CH}_{2} \mathrm{CH}_{2} \mathrm{O}\right)_{\mathrm{n}}\right) ; 3.30-2.80 \quad\left(23.56 \mathrm{H}\right.$ (24), m, PEG- $\underline{\mathrm{CH}}_{2}-\mathrm{O}-$ $\left.\mathrm{DMT}+-\mathrm{NH}-\mathrm{CH}_{2}-\mathrm{CH}(\mathrm{OH})-\underline{\mathrm{CH}}_{2}-\mathrm{NH}-\right)$.

An ice-cooled solution of $(\mathrm{DMT})_{4}-$ pentaPEG $_{2000}-(\mathrm{OH})_{4}$ (0.64 g , 0.053 mmoles) in anhydrous dichloroethane (DCE) (3 ml) was slowly added dropwise, under stirring, to a $6 \%$ solution of trichloroacetic acid (TCA) in DCE (15 ml). Once the addition was complete, stirring was continued, at room temperature, for 30 minutes. The product was precipitated by slow addition of anhydrous ethyl ether, recovered by filtration under vacuum, and washed with ether. This procedure was repeated again to completely remove the DMT group. $(\mathrm{OH})_{4}$-pentaPEG ${ }_{2000}-(\mathrm{OH})_{4}$ was recrystallised from DCM/ether and dried over $\mathrm{KOH}$ under vacuum (0.54 g, 99\%).

${ }^{1} \mathrm{H}-\mathrm{NMR}\left(\mathrm{DMSO}-d_{6}\right) \delta 7.35(2.00 \mathrm{H}(2), \mathrm{m}, \mathrm{NH}$ urethane); 7.19 (4.23H (4), m, NH urethane); 7.07 (4.05H (4), $\mathrm{m}, \mathrm{NH}$ urethane); $4.82(3.32 \mathrm{H}(4), \mathrm{m}, \mathrm{OH}) ; 4.56(3.95 \mathrm{H}(4)$, $\mathrm{m}, \mathrm{OH}) ; 4.08$ (23.45H (24), m, PEG- $\mathrm{CH}_{2}-\mathrm{O}-\mathrm{CO}-\mathrm{NH}-+-\mathrm{O}-$ $\left.\mathrm{CO}-\mathrm{NH}-\mathrm{CH}\left(\mathrm{CH}_{2}-\mathrm{O}-\ldots\right)_{2}+-\mathrm{NH}-\mathrm{CH}_{2}-\underline{\mathrm{CH}}(\mathrm{OH})-\mathrm{CH}_{2}-\mathrm{NH}-\right)$; 3.66-3.38 (909H (909), m, $\left.\left(\mathrm{CH}_{2} \mathrm{CH}_{2} \mathrm{O}\right)_{\mathrm{n}}\right) ; 3.20-3.00(16.82 \mathrm{H}$ (16), m, $\left.-\mathrm{NH}-\mathrm{CH}_{2}-\mathrm{CH}(\mathrm{OH})-\mathrm{CH}_{2}-\mathrm{NH}-\right)$.

\subsubsection{Synthesis of pentaPEG $\mathrm{F}_{2000^{-}}(\mathrm{OH})_{12}(\mathrm{C})$}

$(\mathrm{OH})_{4}$-pentaPEG ${ }_{2000}-(\mathrm{OH})_{4}(0.52 \mathrm{~g}, 0.048 \mathrm{mmoles})$ was coevaporated twice from anhydrous DCM $(10 \mathrm{ml})$ in a 250 $\mathrm{ml}$ flask and dried for 30 minutes under vacuum. The residue was dissolved in a mixture of anhydrous DCM, ACN and pyridine in a $3: 2: 1$ ratio $(3 \mathrm{ml})$ and was mixed with 12.0 equivalents of $\mathrm{N}, \mathrm{N}$ '-disuccinimidyl carbonate $(147.5 \mathrm{mg}$, $0.576 \mathrm{mmoles})$. The mixture was left to react under stirring, at room temperature, for $18 \mathrm{hs}$. The product was precipitated by slow addition of anhydrous ethyl ether $(100 \mathrm{ml})$, recov- 
ered by filtration under vacuum, washed with ether, and dried over $\mathrm{KOH}$ under vacuum. $(\mathrm{OSu})_{4}$-pentaPEG $\mathrm{p}_{2000}-(\mathrm{OH})_{4}$ was recrystallised from DCM/ether $(0.50 \mathrm{~g}, 99 \%)$.

${ }^{1} \mathrm{H}-\mathrm{NMR}\left(\mathrm{CDCl}_{3}\right) \delta 5.80$ (8.93H (10), m, NH urethanes); $4.45\left(8.45 \mathrm{H}(8), \mathrm{m}, \mathrm{PEG}-\mathrm{CH}_{2}-\mathrm{O}-\mathrm{CO}-\mathrm{OSu}\right) ; 4.20(23.13 \mathrm{H}$ (24), m, PEG- $\mathrm{CH}_{2}-\mathrm{O}-\mathrm{CO}-\mathrm{NH}-+-\mathrm{O}-\mathrm{CO}-\mathrm{NH}-\mathrm{CH}\left(\mathrm{CH}_{2}-\mathrm{O}-\right.$ $\left.\ldots)_{2}+-\mathrm{NH}-\mathrm{CH}_{2}-\mathrm{CH}(\mathrm{OH})-\mathrm{CH}_{2}-\mathrm{NH}-\right) ; \quad 3.77-3.40 \quad(909 \mathrm{H}$ (909), m, $\left.\left(\mathrm{CH}_{2} \mathrm{CH}_{2} \mathrm{O}\right)_{\mathrm{n}}\right)$; 3.25-2.95 (17.11H (16H), m, -NH$\left.\underline{\mathrm{CH}}_{2}-\mathrm{CH}(\mathrm{OH})-\underline{\mathrm{CH}}_{2}-\mathrm{NH}-\right)$.

$(\mathrm{OSu})_{4}$-pentaPEG ${ }_{2000}-(\mathrm{OH})_{4}(0.49 \mathrm{~g}, 0.043 \mathrm{mmoles})$ was coevaporated from anhydrous DCM $(10 \mathrm{ml})$ in a $250 \mathrm{ml}$ flask and dried for 30 minutes under vacuum. The residue was dissolved in anhydrous DCM $(3 \mathrm{ml})$ and the resulting solution was mixed with 12.0 equivalents of 2-amino-1,3propandiol (47.0 mg, 0.516 mmoles). The mixture was left to react under stirring, at room temperature, for $18 \mathrm{~h}$. The product was precipitated by slow addition of anhydrous ethyl ether, recovered by filtration under vacuum, washed with ether, dried over $\mathrm{KOH}$ under vacuum, and recrystallised from DCM/ether $(0.43 \mathrm{~g}, 97 \%)$.

Purification was carried out by molecular exclusion chomatography using a Superdex ${ }^{\mathrm{TM}} 75$ resin (Amersham Biosciences, Pittsburgh, PA (USA)) on a 2.6 x $58 \mathrm{~cm}$ column. Crude MultiPEG $(0.20 \mathrm{~g})$ was eluted with $\mathrm{H}_{2} \mathrm{O}$ milliQ at a $0.8 \mathrm{ml} / \mathrm{minute}$ flow. The fractions $(10 \mathrm{ml})$ were collected following their refractive index and those containing the product were combined and evaporated to dryness under vacuum; the residue was extracted with $\mathrm{AcCN}$ and stirred for 30 minutes. The organic solution was dehydrated over anhydrous $\mathrm{Na}_{2} \mathrm{SO}_{4}$ and concentrated under vacuum. The final product $(0.12 \mathrm{~g}, 60 \%)$ was precipitated with anhydrous ether, filtered, washed with ether, and dried over $\mathrm{KOH}$ under vacuum.

${ }^{1} \mathrm{H}-\mathrm{NMR}$ (DMSO- $\left.{ }_{d} 6\right) \delta$ 7.25-6.25 (15.12H (14), m, NH urethanes); 4.85 (4.08H (4), m, $\underline{\mathrm{CH}}-\mathrm{NH}-\mathrm{CO}-\mathrm{O}-. .) ;$. $(3.95 \mathrm{H}(4), \mathrm{m}$, secondary $\mathrm{OH}) ; 4.56(8.02 \mathrm{H}(8), \mathrm{m}$, primary $\mathrm{OH})$; 4.60-4.30 (11.95H (12), m, $-\mathrm{CH}\left(\mathrm{CH}_{2}-\mathrm{O}-\mathrm{CO}-\mathrm{NH}-\ldots\right)_{2}+$ ..-CO-O-NH- $\left.\underline{\mathrm{CH}}\left(\mathrm{CH}_{2}-\mathrm{OH}\right)_{2}\right)$; 4.25-3.85 $(20.41 \mathrm{H}$ (20), m, PEG- $\left.\mathrm{CH}_{2}-\mathrm{O}-\overline{\mathrm{CO}}-..\right) ; \quad 3.63-3.30 \quad(909.1 \mathrm{H} \quad$ (909.1, s, $\left.\left(\mathrm{CH}_{2} \mathrm{CH}_{2} \mathrm{O}\right)_{n}\right) ; \quad 3.20-2.85 \quad(12.11 \mathrm{H} \quad(12) ; \quad \mathrm{m}, \quad-\mathrm{NH}-$ $\left.\underline{\mathrm{CH}}_{2}-\mathrm{CH}(\mathrm{OH})-\underline{\mathrm{CH}}_{2}-\mathrm{NH}-\right)$.

\subsection{Synthesis of tetraPEG $6000-(\mathrm{OH})_{10}$}

\subsubsection{Synthesis of the $(\mathrm{DMT})_{2}-\mathrm{diPEG}_{6000^{-}} \mathrm{OH}(\mathrm{D})$}

1,3-diamino-2-propanol (7.7 $\mathrm{mg}, 0.085$ mmoles ) was dissolved in a 1:1 mixture of anhydrous AcCN and DMF (2 $\mathrm{ml})$ in a $100 \mathrm{ml}$ flask and stirred. 1.8 equivalents of DMT$\mathrm{PEG}_{6000}$-OSu (1.0 g, 0,155 mmoles).were added portionwise over $2 \mathrm{~h}$. The mixture was stirred, at room temperature, for 72 hs. The $(\mathrm{DMT})_{2}-\mathrm{diPEG}_{6000}-\mathrm{OH}(0.98 \mathrm{~g}, 99 \%)$ was precipitated in an ice bath with anhydrous ethyl ether, washed with 2-propanol and ether, and dried over $\mathrm{KOH}$ under vacuum. The compound was recrystallised from EtOH. The TNBS analysis was unable to detect any residual free amino group.

${ }^{1} \mathrm{H}-\mathrm{NMR} \quad\left(\mathrm{DMSO}_{d} 6\right) \quad \delta \quad 7.45-7.22 \quad(18.12 \mathrm{H} \quad(18), \mathrm{m}$, DMT); 7.07 (1.94H (2), m, NH, urethanes); 6.8 (7.97H (8), d, DMT); 4.80 (1.01H (1), d, OH); 4.48 (0.94H (1), m, - $\mathrm{CH}_{2-}$ $\underline{\mathrm{CH}}(\mathrm{OH})-\mathrm{CH}_{2^{-}}$(linker)); 4.05 (4.06H (4), t, (PEG) $\underline{\mathrm{CH}}_{2}-\mathrm{O}-$ CO-NH-..); 3.67-3.33 (1090.1H (1090.1), s, $\mathrm{CH}_{2} \mathrm{CH}_{2} \mathrm{O}$
(PEG)); 3.10 (3.88H (4), t, (PEG) $\left.\mathrm{CH}_{2}-\mathrm{O}-\mathrm{DMT}\right) ; 2.95-2.65$ (3.67H (4), ,m, $-\underline{\mathrm{CH}_{2}}-\mathrm{CH}(\mathrm{OH})-\underline{\mathrm{CH}}_{2^{-}}$(linker)).

\subsubsection{Synthesis of the $(\mathrm{OH})_{4}$-tetraPEG $\mathrm{G}_{6000^{-}} \mathrm{OH}(\mathrm{E})$}

$(\mathrm{DMT})_{2}-\mathrm{diPEG}_{6000}-\mathrm{OH}(1.0 \mathrm{~g}, 0.078 \mathrm{mmoles})$ was coevaporated twice from anhydrous DCM in a $100 \mathrm{ml}$ threenecked flask and dried for $30 \mathrm{~min}$ under the vacuum. The compound was dissolved in $3 \mathrm{ml}$ of a solution of $\mathrm{CH}_{2} \mathrm{Cl}_{2}$, $\mathrm{AcCN}$ and pyridine in a 5:2:1 ratio. 3.0 equiv. of $\mathrm{DSC}(60.0$ $\mathrm{mg}, 0.234$ mmoles) were added and the solution was allowed to react under argon and with stirring at room temperature for $18 \mathrm{~h}$. The product $(1.0 \mathrm{~g}, 99 \%)$ was precipitated by slow addition of anhydrous ethyl ether in an ice bath, recovered by filtration under vacuum, washed with 2-propanol and ether, and dried over $\mathrm{KOH}$ under vacuum. The product was recrystallised from $\mathrm{EtOH}$.

${ }^{1} \mathrm{H}-\mathrm{NMR}\left(\mathrm{DMSO}_{d} 6\right) \delta 7.50(2.03 \mathrm{H}(2), \mathrm{m}, \mathrm{NH}$, urethanes); 7.45-7.22 (18.07H (18), m, DMT); 6.8 (7.95H (8), d, DMT); 4.55 (1.04H (1), d, $\underline{\mathrm{CH}}-\mathrm{O}-\mathrm{CO}-\mathrm{OSu}) ; 4.05$ (4.10H (4), t, (PEG) $\left.\mathrm{CH}_{2}-\mathrm{O}-\mathrm{CO}-\mathrm{NH}-..\right) ; 3.63-3.31$ (1090.1H (1090.1), s, $\mathrm{CH}_{2} \mathrm{CH}_{2} \mathrm{O}$ (PEG)); 3.10-2.90 (7.87H (8), m, (PEG) $\underline{\mathrm{CH}}_{2}-\mathrm{O}-$ DMT); 2.89 (4.06H (4), m, $-\underline{\mathrm{CH}}_{2}-\mathrm{CH}(\mathrm{OH})-\mathrm{CH}_{2}-$ (linker)).

1,3-diamino-2-propanol (3.9 mg, 0.043 mmoles) in a $1: 1$ mixture of AcCN and DMF (2.5 ml) was dissolved in a 100 $\mathrm{ml}$ flask and stirred. The $\mathrm{pH}$ value was brought to 8 with glacial acetic acid. 1.8 equivalents of (DMT) $)_{2}-\mathrm{diPEG}_{6000^{-}}$ OSu (1.0 g, 0.077 mmoles) were added over $2 \mathrm{~h}$.

The mixture was stirred, at room temperature, for $72 \mathrm{~h}$ The product $(0.97 \mathrm{~g}, 97 \%)$ ) was precipitated with ethyl ether in an ice bath, recovered by filtration under vacuum, washed with 2-propanol and ether, and then dried over $\mathrm{KOH}$ under vacuum. The compound was recrystallised from EtOH. The TNBS analysis of the product confirmed the absence of free, unreacted amino groups. The tetramer yield, as determined by GPC analysis, was higher than $30 \%$.

Purification of (DMT) $)_{4}$-tetraPEG ${ }_{6000}-\mathrm{OH}$ was carried out by dialysis using cellulose ester membranes $(\mathrm{M} . \mathrm{W}$. cut off = $100.000 \mathrm{Da})$. Preassembled dialysis tubes $(10 \mathrm{ml})$ were used (Spectra/Por $^{\circledR}$ Float-A-Lyzer ${ }^{\circledR}$, Spectrum Laboratories Inc., Rancho Dominguez, CA (USA)). $0.30 \mathrm{~g}$ of crude product were dissolved in $10 \mathrm{ml}$ of a $0.05 \mathrm{M}$ water solution of 1,3diaminopropan, $\mathrm{pH}=9.0$, and dialyzed against 1.01 of the same solution. The buffer solutions was replaced every $8 \mathrm{~h}$ for an overall dialysis of $72 \mathrm{~h}$. The solution of $(\mathrm{DMT})_{4}$ tetraPEG $\mathrm{P}_{6000}-\mathrm{OH}$ was concentrated to dryness under vacuum, the product collected with $10 \mathrm{ml}$ of $\mathrm{AcCN}$ and stirred for 30 minutes. The solution was filtered and dehydrated over anhydrous $\mathrm{Na}_{2} \mathrm{SO}_{4}$. The AcCN solution was concentrated under vacuum and the product precipitated with anhydrous ether in an ice bath, filtered, washed again with ether, and dried over $\mathrm{KOH}$ pellets under vacuum. $80 \mathrm{mg}$ (27\%) of purified product were collected.

${ }^{1} \mathrm{H}-\mathrm{NMR}$ (DMSO- $\left.{ }_{d} 6\right)$ $\delta$ 7.47-7.20 (38.78H (40), m, DMT + NH, urethanes); 7.07 (1.67H (2), m, NH, urethanes); 6.8 (15.94H (16), d, DMT); $4.78(0.91 \mathrm{H}(1), \mathrm{d}, \mathrm{OH}) ; 4.70-4.50$ (3.32H (3), m, - $\mathrm{CH}_{2}-\mathrm{CH}(\mathrm{O}-\ldots)-\mathrm{CH}_{2^{-}}$(linker)); $4.05(9.25 \mathrm{H}$ (8), t, (PEG) $\left.\underline{\mathrm{CH}}_{2}-\mathrm{O}-\mathrm{CO}-\mathrm{NH}-..\right) ; \quad 3.75-3.36 \quad(2181.8 \mathrm{H}$ (2181.8), s, $\mathrm{CH}_{2} \mathrm{CH}_{2} \mathrm{O}$ (PEG)); 3.10-2.90 (7.88H (8), t, (PEG) $\left.\underline{\mathrm{CH}}_{2}-\mathrm{O}-\mathrm{DMT}\right) ; 2.95-2.65 \quad\left(11.25 \mathrm{H}\right.$ (12), m, - $\underline{\mathrm{CH}}_{2}-$ $\mathrm{CH}(\mathrm{OH})-\underline{\mathrm{CH}}_{2}-$ (linker)). 


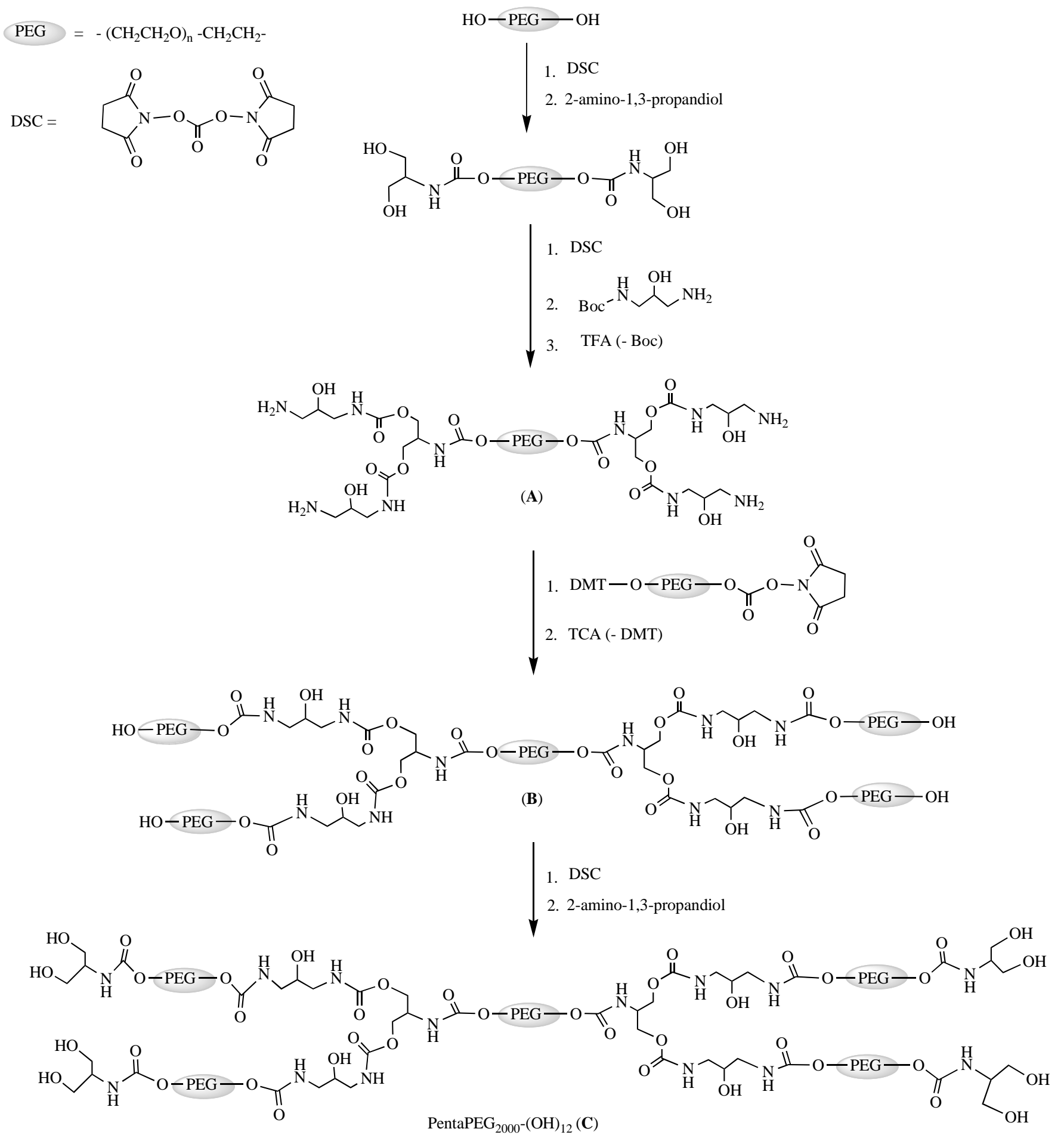

Scheme 1. Assembling of pentaPEG $2000-(\mathrm{OH})_{12}$ starting from a commercial bifunctional $\mathrm{PEG}_{2000}$.

$(\mathrm{DMT})_{4}$-tetraPEG${ }_{6000}-\mathrm{OH}(1.03 \mathrm{~g}, 0.040 \mathrm{mmoles})$ was dissolved in anhydrous DCE $(3 \mathrm{ml})$ in a $250 \mathrm{ml}$ flask in an ice-bath, and a solution of TCA in DCE (6\% (w/v), $15 \mathrm{ml})$ was added dropwise under stirring. The mixture was left to react at room temperature for 30 minutes under stirring. The reaction mixture was concentrated under vacuum and the product was precipitated by slow addition of anhydrous ether $(100 \mathrm{ml})$ in an ice bath, filtered, washed with diethyl ether and dried over $\mathrm{KOH}$ pellets under vacuum. The removal of DMT was repeated under the conditions previously de- scribed. TetraPEG $6000-(\mathrm{OH})_{5}(1.0,99 \%)$ was recrystallised from $\mathrm{DCM} / \mathrm{ether}$ and dried over $\mathrm{KOH}$ under vacuum.

${ }^{1} \mathrm{H}-\mathrm{NMR}$ (DMSO- 6 6) $\delta 7.24$ (4.04H (4), m, NH, urethane); $7.03(2.01 \mathrm{H}(2), \mathrm{m}, \mathrm{NH}$, urethane); $4.83(0.94 \mathrm{H}(1)$, $\mathrm{d}$, secondary $\mathrm{OH}) ; 4.75$ (1.96H (2), m, - NH- $\mathrm{CH}_{2}-\mathrm{CH}(\mathrm{O}-\ldots)-$ $\mathrm{CH}_{2}-\mathrm{NH}-$ ); 4.55 (4.98H (5), m, -NH- $\mathrm{CH}_{2}-\mathrm{CH}(\mathrm{OH})-\mathrm{CH}_{2}-\mathrm{NH}-$ + primary $\mathrm{OH}) ; 4.03$ (8.24H (8), t, (PEG) $\left.\underline{\mathrm{CH}}_{2}-\mathrm{O}-\mathrm{CO}-\mathrm{NH}-..\right)$; 3.65-3.28 (2181.8H (2181.8), s, $\mathrm{CH}_{2} \mathrm{CH}_{2} \mathrm{O}$ (PEG)); 3.052.75 (11.96H (12), m, $-\underline{\mathrm{CH}}_{2}-\mathrm{CH}(\mathrm{OH})-\underline{\mathrm{CH}}_{2}-$ (linker)). 


\subsubsection{Synthesis of the tetraPEG $G_{6000}-(\mathrm{OH})_{10}(\mathrm{~F})$}

TetraPEG $_{6000}-(\mathrm{OH})_{5}(1.00 \mathrm{~g}, 0.041$ mmoles $)$ was coevaporated twice from anhydrous DCM in a $100 \mathrm{ml}$ flask and dried for $30 \mathrm{~min}$ under vacuum. The compound was dissolved in the minimum amount $(3 \mathrm{ml})$ of a solvent mixture of $\mathrm{CH}_{2} \mathrm{Cl}_{2}, \mathrm{AcCN}$ and pyridine in a 5:2:1 ratio. 15.0 equiv. of DSC (52.4 mg, 0.205 mmoles) were added and the solution was allowed to react under stirring at room temperature for $18 \mathrm{~h}$. TetraPEG $6000^{-}(\mathrm{OSu})_{5}$ was precipitated by slow addition of anhydrous ether in an ice bath, filtered, washed with cold 2-propanol and ether, and dried over $\mathrm{KOH}$ pellets under vacuum. The product $(1.02 \mathrm{~g}, 99 \%)$ was recrystallised from EtOH.

${ }^{1} \mathrm{H}-\mathrm{NMR}$ (DMSO- $\left.{ }_{d} 6\right) \delta$ 7.60-7.10 $(5.97 \mathrm{H}(6), \mathrm{m}, \mathrm{NH}$, urethanes); 4.65-4.51 (2.89H (3), m, $-\mathrm{NH}-\mathrm{CH}_{2}-\mathrm{CH}(\mathrm{O}-\ldots)-$ $\left.\mathrm{CH}_{2}-\mathrm{NH}-\right) ; 4.45$ (7.87H (8), t, (PEG) $\left.\mathrm{CH}_{2}-\mathrm{O}-\mathrm{CO}-\mathrm{O}-\mathrm{Su}\right) ; 4.03$ (8.23H (8), t, (PEG) $\left.\mathrm{CH}_{2}-\mathrm{O}-\mathrm{CO}-\mathrm{NH}-..\right) ; 3.75-3.25(2181.8 \mathrm{H}$ (2181.8), s, $\left.\left(\mathrm{CH}_{2} \mathrm{CH}_{2} \mathrm{O}\right)_{\mathrm{n}}(\mathrm{PEG})\right) ; 3.20-2.90$ (11.78H (12), m, $\left.-\mathrm{CH}_{2}-\mathrm{CH}(\mathrm{OH})-\mathrm{CH}_{2}-\right) ; 2.83\left(20.32 \mathrm{H}(20), \mathrm{s}, \mathrm{CH}_{2} \mathrm{CH}_{2}(\mathrm{OSu})\right.$ ).

TetraPEG $_{6000}-(\mathrm{OSu})_{5}(1.00 \mathrm{~g}, 0.041 \mathrm{mmoles})$ was coevaporated twice from anhydrous DCM $(15 \mathrm{ml})$ in a $100 \mathrm{ml}$ flask and dried for 30 min under the vacuum. The compound was dissolved in the minimum amount $(3 \mathrm{ml})$ of anhydrous DCM. 12.0 equivalents of 2-amino-1,3-propandiol $(53.8 \mathrm{mg}$, 0.591 mmoles) were added and the solution was allowed to react under stirring at room temperature for $18 \mathrm{~h}$. TetraPEG $\left._{6000}-(\mathrm{OH})_{10}(0.98 \mathrm{~g}, 98 \%)\right)$ was precipitated by slow addition of anhydrous ether in an ice bath, filtered, washed with cold 2-propanol and ether, and dried over $\mathrm{KOH}$ pellets under vacuum. The product was recrystallised from EtOH.

${ }^{1} \mathrm{H}-\mathrm{NMR}$ (DMSO- $\left.{ }_{d} 6\right) \delta 7.51(1.88 \mathrm{H}(2), \mathrm{m}, \mathrm{NH}$, urethane); $7.20(4.07 \mathrm{H}(4), \mathrm{m}, \mathrm{NH}$, urethane); $6.78(4.12 \mathrm{H}(4)$, d, $\mathrm{NH}$, urethane); 4.65-4.45 (13.31H (13), m, $-\mathrm{CH}_{2}-\mathrm{CH}(\mathrm{O}-$ ...) $\left.-\mathrm{CH}_{2^{-}}+\mathrm{OH}\right) ; 4.07\left(15.97 \mathrm{H}(16), \mathrm{t},(\mathrm{PEG}) \mathrm{CH}_{2}-\mathrm{O}-\mathrm{CO}-\right.$ $\mathrm{NH}-.) ;$.3.70 (3.74H (4), m, -NH-CH$\left.\left(\mathrm{CH}_{2}-\mathrm{OH}\right)_{2}\right) 3.65-3.31$ (2181.8H (2181.8), s, $\mathrm{CH}_{2} \mathrm{CH}_{2} \mathrm{O}$ (PEG)); 3.30-3.00 (12.12H (12), m, $-\underline{\mathrm{CH}}_{2}-\mathrm{CH}(\mathrm{OH})-\underline{\mathrm{CH}}_{2}-$.

\section{RESULTS AND DISCUSSION}

In a previous paper the first examples of high-molecular eight, branched poly(ethylene glycol) derivatives (MultiPEG)s assembled through a dendrimer-like approach were described (25). In this paper we report the preparation of a new set of MultiPEGs that differ from the previous one by an increased number of functional groups and a larger overall molecular weight. To this purpose, two different branching procedures have been devised.

In the first example both the starting PEG and one of the polyfunctional linker have been selectively monoprotected. This synthetic task is quite work-intensive, but it allows preservation of the advantageous properties of the PEGbased structure together with an increase of its loading capacity (up to 6 times compared with linear, commercial PEG of the same size).

The scheme of the first synthesis is represented in the Scheme 1.

The synthetic process can be described in detail as following: first, the $\mathrm{OH}$ functional groups of the starting PEG unit were activated and reacted with the more nucleophilic 2position of the linker 2-amino-1,3-propandiol; then, the new $\mathrm{OH}$ functional groups were activated and a $\mathrm{N}$-monoprotected 1,3-diamino-2-propanol unit was introduced on each reactive moiety. After the removal of the N-protections of the linkers, a selectively monoprotected and activated new starting PEG unit was assembled on the multifunctional core previously obtained. Successively, following a further removal of the OH-protections, a new reaction with 2-amino-1,3-propandiol molecules of the activated, new $\mathrm{OH}$ functional groups gave the desired MultiPEG derivative that was purified by a chromatographic procedure.

The chromatographic patterns of crude and purified pentaPEG ${ }_{2000}-(\mathrm{OH})_{12}$ are reported in Fig. (1).

As observed from the ${ }^{1} \mathrm{H}$ NMR spectra in Fig. (2) and the integration values of significant signals of the intermediate (see experimental section) and of the final product, the use of $\mathrm{N}, \mathrm{N}$ '-disuccinimidyl carbonate, in the reported conditions, did not allow the introduction of the $\mathrm{N}$-monoprotected 2amino-1,3-propandiol even on the internal, secondary groups. As a consequence, only the terminal primary hydroxyls were reacted and their functionalities doubled.

The second procedure was devised to favour the assembling of larger, but less reactive, starting PEG polymers and to allow for a facile production and purification procedure. In particular the work-intensive chromatographic purification of the previous process was substituted by a more convenient dialysis; in fact, the larger dimensions of the new intermedi-

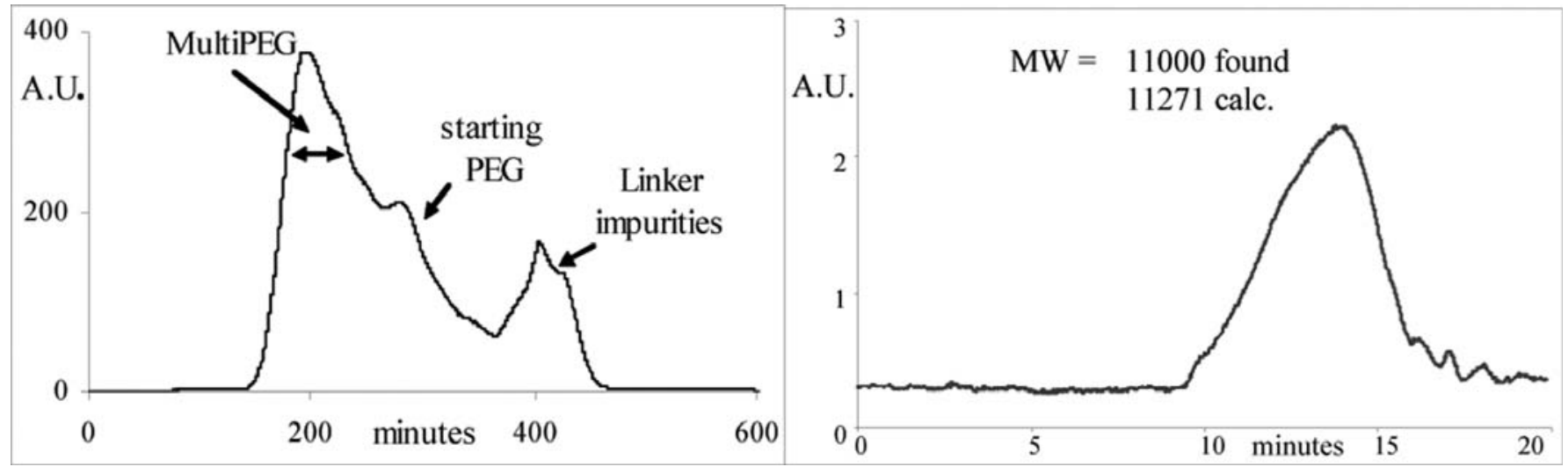

Fig. (1). Low-pressure chromatographic purification (left) and GPC analysis of purified pentaPEG ${ }_{2000}-(\mathrm{OH})_{12}(\mathrm{right})$. 


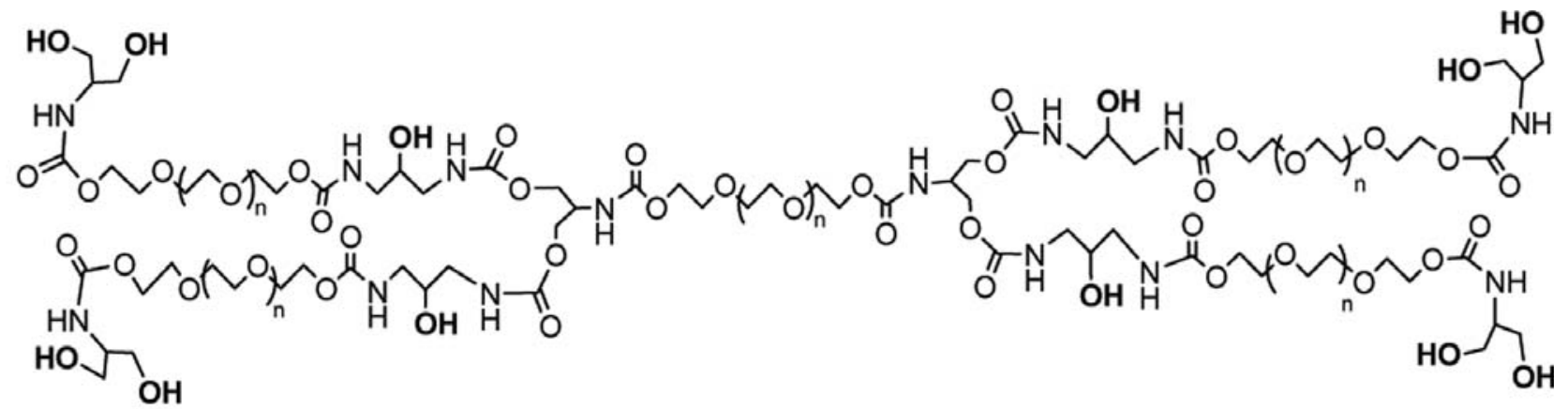

\begin{tabular}{|c|c|}
\hline $\mathbf{A}$ & $\mathrm{NH}$ urethanes \\
\hline B & $\mathrm{CH}-\mathrm{NH}-\mathrm{CO}-\mathrm{O}---$ \\
\hline $\mathbf{C}$ & secondary $\mathrm{OH}$ \\
\hline D & primary $\mathrm{OH}$ \\
\hline E & $\begin{array}{l}-\mathrm{CH}-\left(\mathrm{CH}_{2}-\mathrm{O}-\mathrm{CO}-\mathrm{NH}---\right)_{2}+ \\
{ }_{2}\left(\mathrm{HO}-\mathrm{CH}_{2}\right)-\underline{\mathrm{CH}}-\mathrm{NH}-\mathrm{CO}-\mathrm{O}-\end{array}$ \\
\hline $\mathbf{F}$ & $\mathrm{PEG}-\mathrm{CH}_{2}-\mathrm{O}$ \\
\hline $\mathbf{G}$ & $\left(-\mathrm{CH}_{2}-\mathrm{CH}_{2}-\mathrm{O}\right)_{n}$ \\
\hline
\end{tabular}

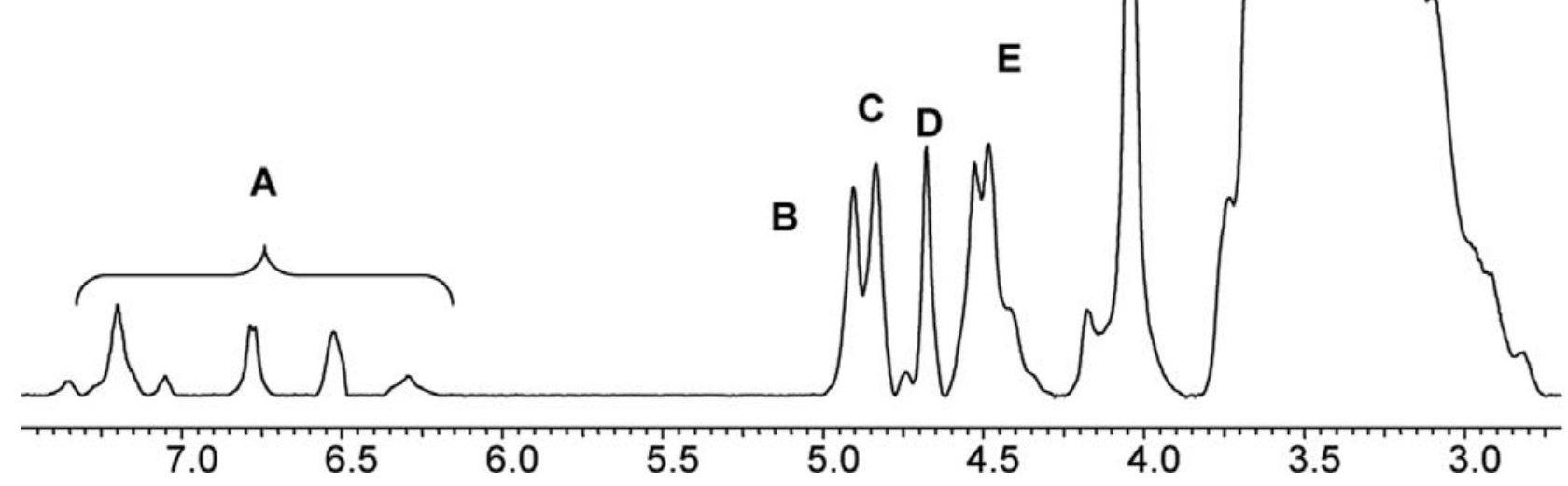

Fig. (2). ${ }^{1} \mathrm{H}$ NMR spectrum of the pentaPEG ${ }_{2000^{-}}(\mathrm{OH})_{12}$ in DMSO-d ${ }^{6}$.

ates assured for an efficient performance of this procedure. In contrast, the synthetic scheme described before was not particularly efficient if applied to PEG molecules larger than $3000 \mathrm{Da}$.

The scheme of the second synthesis is represented in the Scheme 2.

This alternative synthetic process can be described as following: initially, a selective monoprotection of the starting PEG chain was achieved and the remaining, free $\mathrm{OH}$ group activated as before. Then, a protected PEG dimeric component was assembled by joining two of these units using 1,3-diamino-2-propanol as a linker. By repeating this process through a further activation of the new $\mathrm{OH}$ functional groups of the dimer and the use of the same linker molecule a final tetrameric core was assembled. After a dialysis purification to eliminate lower-size byproducts from the mixture, the removal of $\mathrm{OH}$-protections and the final introduction of 2-amino-1, 3-propandiol on the activated, new $\mathrm{OH}$ functional groups gave the desired MultiPEG derivative.
The chromatographic patterns of the crude and purified tetraPEG ${ }_{6000^{-}}(\mathrm{OH})_{10}$ are reported in Fig. (3).

From the GPC evaluation of the final molecular weights, is possible to observe some small differences between the calculated and the observed values, but these are most likely due to the small structural diversities of the standard PEGs used to calibrate the column. Moreover, the ${ }^{1} \mathrm{H}-\mathrm{NMR}$ spectrum reported in Fig. (4) confirms the attainment of the expected derivative on the basis of the signals and of their integral values (see experimental part).

Then, using the planned processes, multifunctional, branched polyethylene glycol derivatives (MultiPEG) were formed by assembling single PEG units of the same size through successive condensation reactions in a divergent, dendrimeric fashion. The success of this procedure was obviously based on the production of adequate amounts of starting bifunctional PEG protected at only one of its two starting reactive ends. We addressed this selective monoderivatisation of the starting polydisperse PEGs by using a proper excess of the protecting reagent; its amount was care- 


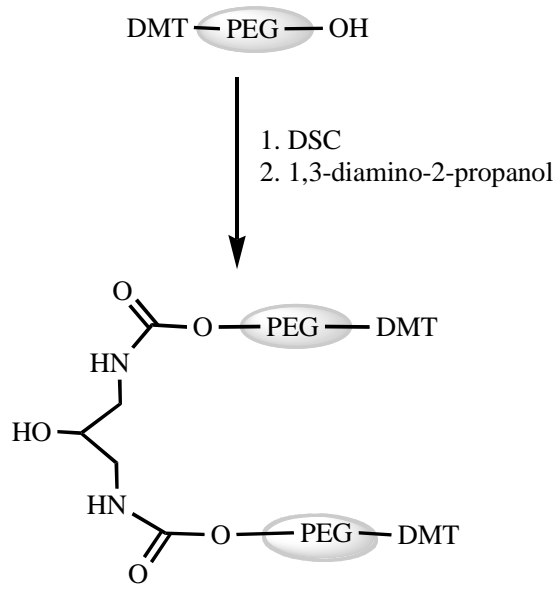

(D)

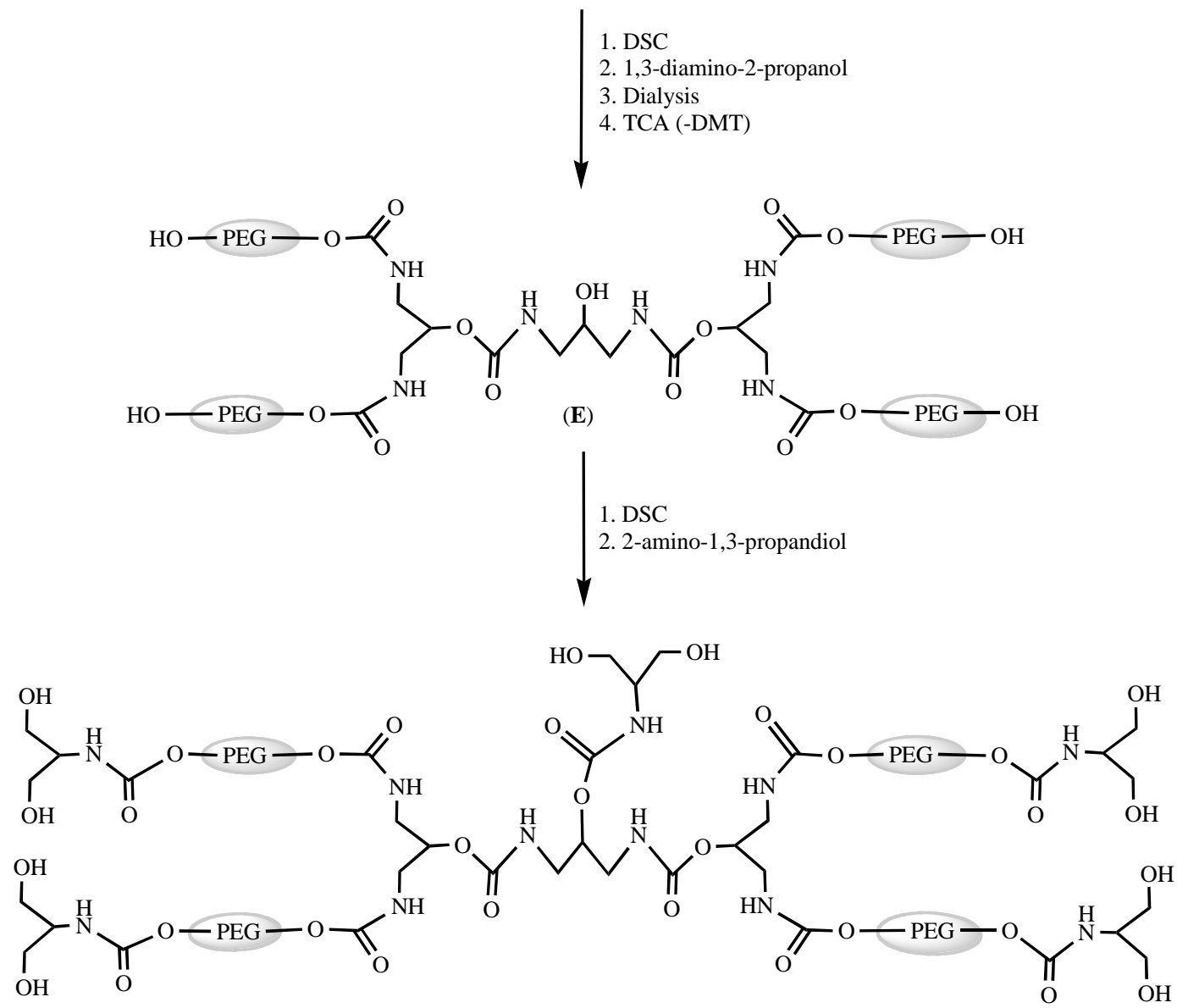

TetraPEG $_{6000^{-}}(\mathrm{OH})_{10}(\mathrm{~F})$

Scheme 2. Assembling of tetraPEG $6000-(\mathrm{OH})_{10}$ starting from a commercial bifunctional $\mathrm{PEG}_{6000}$.

fully evaluated to avoid any presence in the final mixture of the starting unreacted polymer, but producing the maximum amount of the monoprotected polymer. Some double protected polymer was eventually present, but it did not further react during the successive assembling of the multimeric structure, allowing for an efficient final separation simply on the basis of its lower molecular weight.
For a sake of comparison of the two procedures, the two novel MultiPEGs, retaining all physicochemical characteristics of the started polyether skeleton, are compared in term of synthetic steps, final product, dimension and loading value (Table 1). A different balance between loading values and final molecular size following the two assembling procedures is observed. Moreover, since the purification steps played a critical role in the final yield of the process, this 


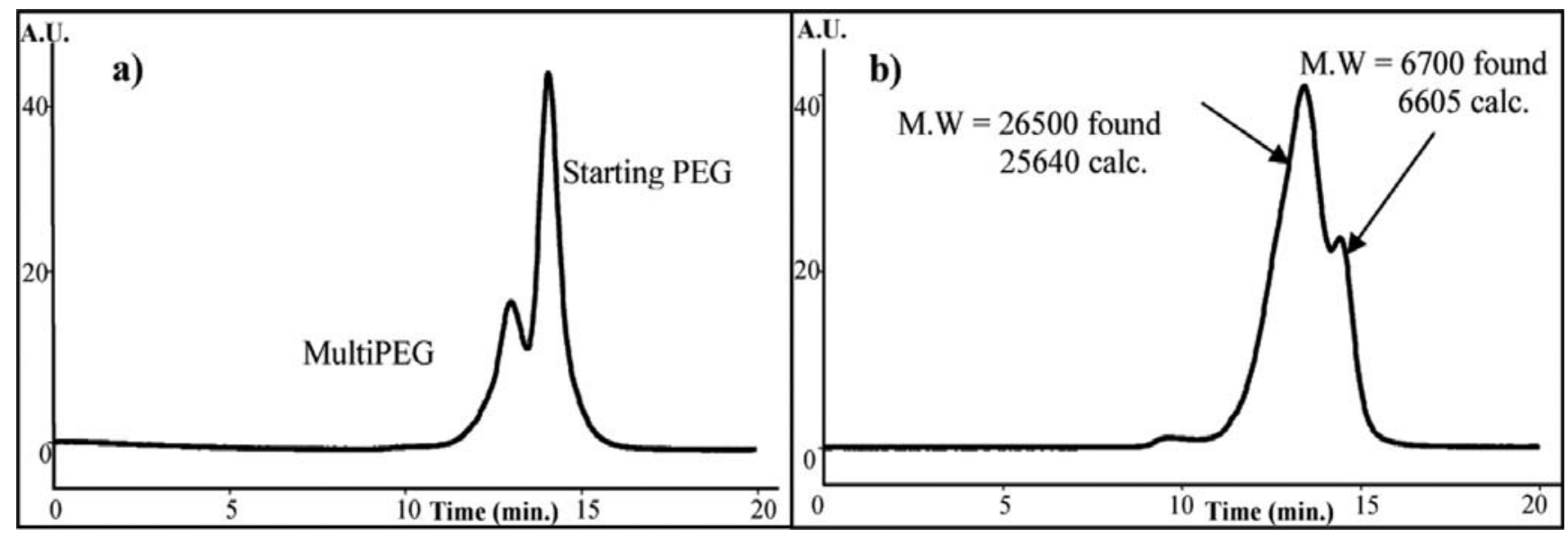

Fig. (3). GPC of (DMT) $)_{4}$-tetraPEG ${ }_{(6000)}-\mathrm{OH}$ a) crude; b) purified by extensive dialysis.

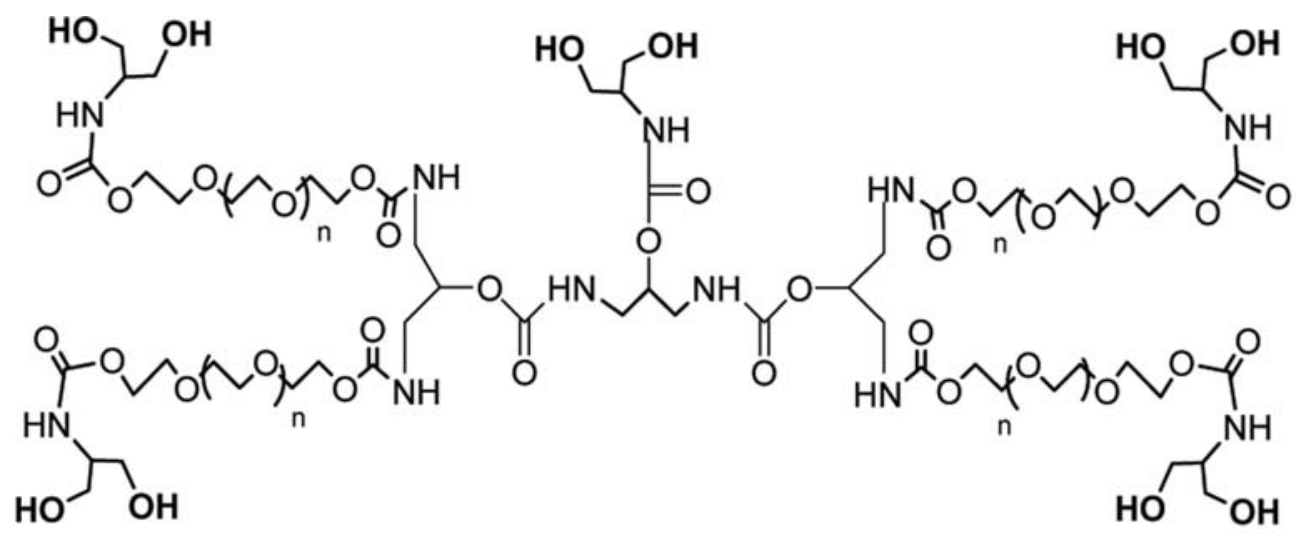

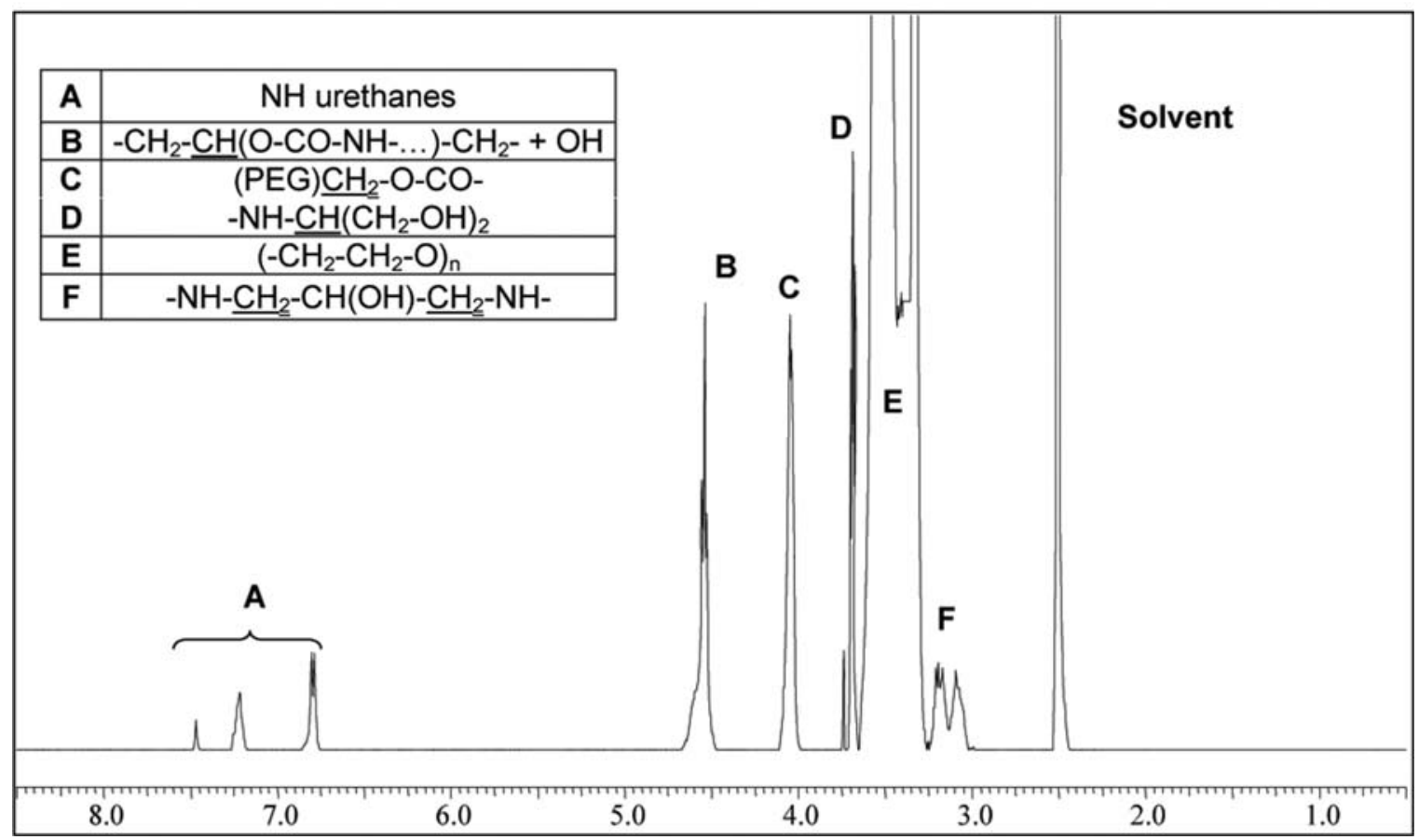

Fig. (4). ${ }^{1} \mathrm{H}-\mathrm{NMR}$ in DMSO- $d_{6}$ of tetraPEG ${ }_{6000}-(\mathrm{OH})_{10}$. 
Table 1. Evaluation of Synthetic Data of the Two New MultiPEGs

\begin{tabular}{|c|c|c|c|c|c|}
\hline MultiPEG & Final M.W. & Increased loading value $^{\text {a }}$ & Reaction steps $^{\text {Type of purification }}$ & Amount of product $^{\text {b }}$ \\
\hline \hline pentaPEG $_{2000^{-}}(\mathrm{OH})_{12}$ & 11.271 & $6 \mathrm{X}$ & 12 & Low-pressure gel filtration & $0.40 \mathrm{~g}$ \\
\hline tetraPEG$_{6000}-(\mathrm{OH})_{10}$ & 25.640 & $5 \mathrm{X}$ & 8 & Dialysis & $0.25 \mathrm{~g}$ \\
\hline
\end{tabular}

a compared to commercial, linear bifunctional PEGs; ${ }^{\mathrm{b}}$ obtained from $1.0 \mathrm{~g}$ of starting PEG.

aspect should be evaluated taking in account the overall time required for the complete production of the desired product.

\section{CONCLUSIONS}

PEG conjugation is expected to maintain in the near future a leading position in the development of drug delivery systems for its broad applicability, efficiency and convenient cost. Additionally, it could be easily conceived that this polymer will represent a possible solution for new supported synthetic processes. Consequently, new synthetic routes aimed to the production of functionally expanded PEG reagent are certainly of interest. As far as the preparation of these MultiPEGs is concerned, some laborious steps are undoubtedly necessary during the synthetic process, but, on the other hand, the proposed procedures will assure a better homogeneity of the final polymeric product in comparison with similar procedures that do not use pure, monoprotected building units. Moreover, even if the reported synthetic processes have been performed on a gram scale, a scaling up could be reasonably afforded for commercial purposes. It should be also noted that the introduction of new urethane bonds within the final polyether backbone will likely allow for more advantageous biodegradability properties in comparison with other similar branched derivatives. Eventually, a more advantageous PEG chain degradation could be observed; in fact, some hydrolysis at the level of the urethane bond is expected to take place [27,28]. Also, it should be emphasized that the use of low-dispersed polymers as starting building units will also guarantee the same level of polydispersity for the larger, final MultiPEG.

It should be further recalled that commercial PEG polymers usually carry only one or two sites available for drug conjugation, but with these MultiPEGs up to six times more new molecules can be loaded in comparison with linear, commercial polymers of the same size. This in principle will allow the administration of a correspondingly lower amount of polymer of the same size, to achieve the same level of drug concentration within the body, when used as carrier for pharmacological purposes. The high molecular weight of these polymeric supports is another important feature, since a long lasting release can be observed using large size polymer derivatives [29]. Additionally, from the point of view of its synthetic applications, an increased production level for the same starting amount of the soluble, inert support can be easily envisaged.

In conclusion, these MultiPEGs could offer new advantages in comparison with similar branched polymeric derivatives, from the point of view of both pharmacological and synthetic applications, and will be subject of future evaluations for their practical applications.

\section{ACKNOWLEDGEMENT}

This work was financially supported by Progetto SISTER-Science Research Area - University of Trieste and by MIUR (Italy) (PRIN2003 - PRIN2005)

\section{REFERENCES}

[1] Davis, F.F. Adv. Drug Deliv. Rev., 2002, 54, 457.

[2] Vellard, M. Curr. Opin. Biotechnol., 2003, 14, 444.

[3] Greenwald, R.B.; Choe, Y.-H.; McGuire, J.; Conover, C.D. Adv Drug Deliv Rev., 2003, 55, 217.

[4] Zalipky, S.; Zilka, G. Eur. Polym. J., 1983, 19, 1177.

[5] Pendri, A.; Gilbert,C.W.; Soundararajan, S.; Bolikal, D.; Shorr, R. G.L.; Greenwald R. B. J. Bioact. Compat. Polym., 1996, 11, 122.

[6] Greenwald, R.B.; Conover, C. D.; Pendri, A.; Choe, Y.-H.; Martinez, A.; Wu, D.; Guan, S.; Yao, Z.; Shum, K.L. J. Control. Release, 1999, 61, 281.

[7] Ooya, T.; Lee, J.; Park, K. J. Control. Releas, 2003, 93, 121.

[8] Pasut, G.; Scaramuzza, S.; Schiavon, O.; Mendichi, R.; Veronese, F.M. J. Bioact. Compat. Polym., 2005, 20, 213.

[9] Na, D.H.; Lee, C.K.; DeLuca, P.P. Pharm. Res., 2005, 22, 743.

[10] Lee, J.-H.; Canny, D.M.; De Erkenez, A.; Krilleke, D.; Ng, Y.-S.; Shina, D.T.; Pardi, A.; Jucker, F. Proc. Natl. Acad. Sci. USA, 2005 , 102, 18902.

[11] Na, D.H.; De Luca, P.P. Pharm. Res., 2005, 22, 736.

[12] Sedlak, M. Collect. Czech. Chem. Commun., 2005, 70, 269.

[13] Gallivan, J.; Jordan, J.P.; Grubbs, R.H. Tetrahedron Lett., 2005, 46 , 2577.

[14] Zhao, H.; Greenwald, R.B.; Reddy, P.; Xia, J.; Peng, P. Bioconjug. Chem., 2005, 16, 758 .

[15] Benaglia, M.; Annunziata, R.; Cinquini, M.; Cozzi, F.; Ressel, S. J. Org. Chem., 1998, 63, 8628 .

[16] Reed, N.N.; Janda, K.D. Org. Lett., 2000, 2, 1311

[17] Guiotto, A.; Pozzobon, M.; Sanavio, C.; Schiavon, O.; Orsolini, P.; Veronese, F. M Bioorg. Med. Chem. Lett., 2002, 12, 177.

[18] Monfardini, C.; Schiavon, O.; Caliceti, P.; Morpurgo, M.; Harris, M.J.; Veronese, F.M. Bioconjug. Chem., 1995, 6, 62.

[19] Harris, J.M.; Veronese, F.M.; Caliceti, P.; Schiavon, O.; U.S. Patent $5,932,462$, August $3,1999$.

[20] Fishman, M., Farrah, E.; Zhong, J.-H.; Paramanantham, S.; Carrera, C.; Lee-Ruff, E. J. Org. Chem., 2003, 68, 9843.

[21] Gillies, E.R.; Fréchet, J.M. Drug Discov. Today, 2005, 10, 35.

[22] Haag, R.; Sunder, A.; Stumbé, J.-F. J. Am. Chem. Soc., 2000, 122, 2954.

[23] Ihe, H.; De Jesús, O.L. P.; Fréchet, J. M. J. Am. Chem. Soc., 2001, 123,5908 .

[24] Sunder, A.; Mülhaupt, R.; Haag, R.; Frey, H. Macromolecules, 2000, 33, 253 .

[25] Ballico, M.; Drioli, S.; Bonora, G.M. Eur. J. Org. Chem., 2005 , 2064.

[26] Snyder, S.L.; Sobocinski, P.Z. Anal. Biochem., 1975, 64, 284.

[27] Herold, D. A.; Keil, K.; Bruns D. E. Biochem. Pharmacol.,1989, 38,73 .

[28] Guiotto, A.; Canevari, M.; Pozzobon, M.; Moro, S.; Orsolini, P.; Veronese F.M. Bioorg. Med. Chem., 2004, 12, 5031.

[29] Zacchigna, M.; Di Luca, G.; Cateni, F.; Maurich, V.; Ballico, M.; Bonora, G.M., Drioli, S. Eur. J. Pharm. Sci., 2007, 30, 343. 